\title{
Impacts, Waste Generation and Green House Gas Emission by Nepalese Poultry Industry
}

\author{
Tej Kumar Shrestha ${ }^{1,2^{*}}$, Sarita Lawaju ${ }^{1}$, Anish Parajuli ${ }^{1}$, Renuka Baidhya ${ }^{1}$, Sandhya \\ Manandhar $^{1}$, Sunita Shrestha ${ }^{1,3}$, Roshik Shrestha ${ }^{1,4}$, Pawan Paudyal ${ }^{1}$, Bijaya Mishra ${ }^{1}$, Bijay $^{2}$ \\ Maharjan ${ }^{1}$ \\ ${ }^{1}$ Lumbini Environmental Services Pvt. Ltd., Kathmandu, Nepal \\ ${ }^{2}$ Khwopa College, Dekocha, Bhaktapur, Nepal \\ ${ }^{3}$ National Academy of Medical Sciences, Kathmandu, Nepal \\ ${ }^{4}$ Nepal Polytechnique Institute, Chitwan, Nepal
}

*Corresponding Author: Tej Kumar Shrestha, Lumbini Environmental Services Pvt. Ltd., Khwopa College, Dekocha, Bhaktapur

\begin{abstract}
Poultry farming is an emerging industry in Nepal. The poultry sector's growth and trends towards intensification have given rise to a number of environmental concerns. Hygienic poultry production can pave way to better income and sustainable development but poor sanitation and waste management lead to the contamination of fresh water sources becoming a major cause of disease, death and deterioration of the health of eco-systems. This study was undertaken to assess and estimate the environmental impacts, composition of waste generation and methane gas emission from poultry farm. Impacts from the poultry farm were identified and evaluated through environmental assessments of four poultry farms. Nepal Commercial Poultry Survey 2015 was reviewed, analyzed, interpreted and evaluated to estimate composition of waste and methane emission in Nepal. It was found that change in land use pattern, waste generation, odor generation, air pollution, noise pollution, water pollution, soil pollution and decrease in aesthetic beauty were adverse physical impacts from poultry farm. Transmission of zoonotic disease, increase in number of flies were the adverse biological environment associated with poultry operation. Operation of poultry adversely affect the occupational health and safety of workers through exposure to different safety hazards and odor, dust and pathogens transmitted from live birds, excreta, carcasses and parasites. The annual liquid waste and solid waste production from poultry industry in Nepal is 618.86 million liters and 2.7 million tons respectively. $81.91 \%$ of liquid waste generated from sullage and $18.09 \%$ from sewage. $99 \%$ of poultry solid waste was generated from poultry manure i.e. 2.66 million tons/year. Poultry farm in Nepal emit 30.41 Gg CO2-eq of methane gas (CH4) annually from manure management.
\end{abstract}

Keywords: Poultry, Environment, Waste, Impact, GHG

\section{BACKGROUND}

Nepal is an agricultural country where $68 \%$ of people are dependent upon agriculture for their livelihood (USAID, 2019). Total Gross Domestic Product (GDP) contribution of Agriculture sector in Nepal is $33.7 \%$, out of which poultry sector contributes about 3.5\% of GDP (CBS, 2012). Poultry are domesticated avian species that can be raised for eggs and meat. The term "poultry" covers a wide range of birds, from indigenous and commercial breeds of chickens to muscovy ducks, mallard ducks, turkeys, guinea fowl, geese, quail, pigeons, ostriches and pheasants (FAO, 2019).

Poultry farming is an emerging industry in Nepal. An increasing human population, greater purchasing power and urbanization have been strong drivers for the growth and industrialization of poultry sector in many parts of the world (FAO, 2014). Commercial poultry production is growing rapidly by more than three times in recent years (between 1985 to 2014) (Acharya \& Kaphle, 2015). There are 21,956 poultry farms in Nepal which rear 60.83 million birds annually. There are 3,561 (16\%), 2,096 (10\%), 7638 (35\%), 2,993 (14\%), 3,691 (17\%), $864(4 \%)$ and 1,113 (5\%) poultry farms in 1, 2, 3, Gandaki, 5, Karnali and Sudurpaschim province respectively. Among them 20,483 (93.29\%) farms are established for rearing boilers, 13,037 (6.09\%) farms are exclusively for rearing layers, $128(0.58 \%)$ farms for hatchery and $8(0.04 \%)$ farms for rearing Giriraj/Koiler. Around 52.66 
million (87\%) boilers, 6.9 million (11\%) layers and 1.2 million $(2 \%)$ other bird species (i.e. parent birds, Koiler, etc) are produced annually in Nepal. Annually 1.2 billion table eggs are produced in Nepal (CBS, 2016). Average annual growth rate of poultry egg production has been $2.43 \%$ during last ten years (Osti et al., 2016). The number of laying poultry as compared to fiscal year 2015/16 is estimated to rise by $32.1 \%$ reaching 12.39 million in fiscal year 2016/17. The production of chicken has risen to $25.4 \%$ compared to fiscal year 2015/16 reaching 70 million in fiscal year 2016/17 (MoF, 2018). The major commercial breeds in Nepal are Cobb 100, Cobb 500, Vencobb 100, Kashila, Lohmann, H \& N, Hyline, Marshall, and Rose 308 (Mishra, 2013).

\subsection{Environmental Impacts of Poultry Farms}

Rapid growth and intensification of poultry sector have given rise to a number of environmental concerns in local production settings, regional level as well as global scales (Gerber, Opio, \& Steinfeld, 2007). Hygienic poultry production can pave way to better income and sustainable development (Sharma, 2010) but poor sanitation and waste management lead to the contamination of fresh water sources becoming a major cause of disease, death and deterioration of eco-system health (United Nations Economic and Social Commission for Asia and the Pacific (ESCAP), United Nations Human Settlements Programme (UN-Habitat), Asian Institute, 2015). Poor management of manure, bird carcasses, dust, insects, odor, etc. generated from poultry operation adversely affect the environment. Furthermore, intensive poultry production is held responsible for the emission of Greenhouse Gasses $\left(\mathrm{CH}_{4}, \mathrm{CO}_{2}, \mathrm{~N}_{2} \mathrm{O}\right)$, acidification, and eutrophication. The environmental impact of poultry production depends on numerous factors, among which are farm size, production system, diet composition, type of bedding used, etc. (Rodic, Peric, Stojcic, \& Vukelic, 2011). Poultry operation generates odor and attracts disease transmitting vector such as files, rodents and pest. Odor associated with poultry operations comes from fresh and decomposing waste products such as manure, carcasses, feathers and bedding/ litter (Ferket, Van Heugten, Van Kempen, \& Angel, 2002; Kolominskas, Bawden, \& Ormerod, 2002). Flies are an additional concern for residents living near poultry facilities. The most significant environmental issue resulting from poultry operations is the discharge of waste into the environment. Poultry release large amount of waste that include both solid and liquid waste into the environment, polluting land and surface water as well as posing a serious human-health risk (Muduli et.al, 2018).

\subsection{Waste from Poultry}

\section{- Liquid Waste}

Poultry industry generates a significant amount of wastewater. The wastewater generated from poultry operations include effluents from various sources including runoff from poultry housing, feeding, cleaning and disinfection of poultry farm that have the potential to contaminate surface water and groundwater with nutrients, ammonia, sediment, pesticides, pathogens, and feed additives, such as heavy metals, hormones, and antibiotic cs (International Finance Corporation, World Bank Group, 2007). Wastewater in poultry is dependent on the area of poultry farm that determines the number and type of poultry. For example, a deep litter house measuring $6 \mathrm{~m}$ by $11 \mathrm{~m}$ can hold 200 laying hens at a stock density of $3 \mathrm{birds} / \mathrm{m}^{2}$ (3.6 $\mathrm{ft}^{2} / \mathrm{bird}$ ) (Sonaiya \& Swan, 2004). According to EC 2003, annual water consumption for cleaning the areas of poultry is $>0.025 \mathrm{~m}^{3} / \mathrm{m}^{2} /$ year.

\section{- Solid Waste}

Poultry manure is the main source of solid waste in poultry farm. It consists of bedding material mixed with manure, feathers, spilled water and waste feed accumulated in the farm. The manure excreted by 1000 birds per day is approximately $120 \mathrm{~kg}$ for layer chickens (Collins et al., 1999). The manure excreted by 1000 broiler breeder birds is approximately (18143 kg/yr) 24 tons/yr (NRAES, 1999). Dead birds are another main source of solid waste. Mortality rate may rise due to disease, predation or high temperature. The average mortality rate of a flock is from 20 to 25 percent per year (FAO, 2003). According to Nepal Commercial Poultry Survey 2015, mortality rate of birds varies i.e. $12.8 \%$ in boilers, $9.2 \%$ in layers and $7 \%$ in parent birds. Dust from poultry houses originates from feathers, skin particles and used litter, and to a lesser extent from feed, bedding, micro-organisms and fungi. Dust concentrations in poultry houses vary from 0.02 to $81.33 \mathrm{mg} / \mathrm{m}^{3}$ for inhalable dust and from 0.01 to $6.5 \mathrm{mg} / \mathrm{m}^{3}$ for respirable dust. Houses with caged laying hens showed the lowest dust concentrations, i.e., less than $2 \mathrm{mg} / \mathrm{m}^{3}$ (Ellen et.al, 2000). 


\subsection{Greenhouse Gases from Poultry Farm}

Greenhouse gas are emitted from the poultry farm through manure storage and manure treatment. The production of poultry generates greenhouse gas (GHG) emissions, including carbon dioxide $\left(\mathrm{CO}_{2}\right)$, nitrous oxide $\left(\mathrm{N}_{2} \mathrm{O}\right)$ and methane $\left(\mathrm{CH}_{4}\right)$ through respiration by bird, enteric fermentation in digestive tract (Robert, 2012). Poultry is considered to have an environmental advantage compared to many other animal protein sources as it has lower GHG emissions due to their lower enteric methane production rates than ruminant livestock species (Verge, Dyer, Desjardins, \& Worth, 2009). Emission of $\mathrm{CO}_{2}$ from bird respiration and manure are not considered in GHG inventories by the IPCC Guidelines for National GHG inventories as $\mathrm{CO}_{2}$ emission is assumed to be zero on net annual basis. Since the $\mathrm{CO}_{2}$ from respiration and manure management and enteric $\mathrm{CH}_{4}$ and $\mathrm{N}_{2} \mathrm{O}$ are typically not reported in GHG emission inventories for poultry, the storage and handling of poultry manure represents the sources of $\mathrm{N}_{2} \mathrm{O}$ and $\mathrm{CH}_{4}$ emissions associated directly with poultry production system. Combustion of fossil fuel for winter heating and cropping system used to produce poultry feed are included in GHG inventories associated with poultry production (Robert, 2012). Much of the GHGs are generated from the poultry industry primarily from feed production, the utilization of fossil fuels and manure management (Pelletier, 2008).

This research aims to assess the environmental impacts of poultry farm, estimate waste generated, and contribution of $\mathrm{CH}_{4} \mathrm{GHG}$ from Nepalese poultry industry.

\section{Methodology}

\subsection{Study Area}

The study was carried out in four poultry farms located in Nawalparasi, Tanahun and Jhapa districts of Nepal to assess the environmental impacts of poultry farm in 2018. Salient features of the study area are presented in table below;

Table1. Salient features of study area

\begin{tabular}{|c|c|c|c|c|}
\hline \multirow{2}{*}{ Features } & \multicolumn{4}{|c|}{ Description } \\
\cline { 2 - 5 } & Site I & Site II & Site III & Site IV \\
\hline Area & $34,048.23 \mathrm{sq} . \mathrm{m}$ & $24,801 \mathrm{sq} \cdot \mathrm{m}$ & $60,000 \mathrm{sq} . \mathrm{m}$ & $60,000 \mathrm{sq} . \mathrm{m}$ \\
\hline Name of species & Cobb 500 & Cobb 500 & Cobb 500 & Cobb 500 \\
\hline Layers number & 93,000 & 70,000 & 50,000 & 80,000 \\
\hline Workers number & 70 & 61 & 30 & 39 \\
\hline Manure production (tons/yr) & 4073.4 & 3066 & 2190 & 3504 \\
\hline Eggs production (per annum) & $22,320,000$ & $13,000,000$ & $12,000,000$ & $19,200,000$ \\
\hline
\end{tabular}

\subsection{Methods}

\subsubsection{Impact Assessment}

Impacts from the poultry farm were identified and evaluated through environmental assessments of four poultry farms during the study in 2018. Impact checklists were prepared for impact identification through literature review and expert consultation. Field visit was conducted to collect the baseline information of the study area. Consultation was carried out with the local community living near the project site, relevant stakeholders and other key informants to collect the information about the seen and probable environmental impacts of the poultry farm. Random sampling was conducted during household survey with $10 \%$ sampling intensity using questionnaires to gather socio-economic and environmental information of the project area. With the principal aim of collecting relevant biological, socio-economic and cultural environment information, mass meeting at different communities were organized with the key groups such as business entrepreneurs, farmers, and government, nongovernment employers and relevant stakeholders. The environmental impacts were categorized as physical, biological, socio-economic and cultural components on the basis of National EIA Guidelines 1993 of Nepal. Significance of impacts were evaluated based on nature, magnitude, extent and duration of impacts as per the numeric scale mentioned in National EIA guidelines 1993. A score value 60, 20 and 10 were given for high, medium and low magnitude impacts respectively. Similarly, a score value of 60,20 and 10 were given for regional, local, site specific extent of the impacts respectively. Score value of 20,10 and 5 were given for long term, medium term and short term impacts respectively. The combined score less than 50 was termed as insignificant impacts, 50-75 termed as significant impacts and beyond 75 termed as very significant impacts. The impacts of high significance level were only taken into account. 


\subsubsection{Assessment of Waste Generation}

Published and unpublished literature on poultry farms, volume and type of waste both global and national levels were reviewed. Scholarly book, journal articles and thesis on poultry farming were reviewed. The Nepal Commercial Poultry Survey 2015 was reviewed, analyzed, interpreted and evaluated. Emphasis was given to explore the waste generated by poultry in different poultry farms. The total waste of poultry farm was categorized as liquid waste and solid waste.

\section{- Liquid Waste}

The liquid waste from poultry was categorized as sullage and sewage. Sullage included wastewater generated from cleaning and disinfection process in poultry farm. During the cleaning and disinfection process in poultry farm liquid waste might consist of minimum litter of poultry, which was neglected in this study. Similarly, black water i.e. sewage included wastewater from latrine used by workers during poultry operation.

Table2. Liquid waste

\begin{tabular}{|l|l|l|}
\hline S.N. & Categories of liquid waste & Methods \\
\hline 1 & Sullage & Total sullage generated= total area of farm $* 0.025 \mathrm{~m}^{3} / \mathrm{m}^{2} / \mathrm{year}(\mathrm{EC}, 2003)$ \\
\hline 2 & Sewage & $\begin{array}{l}\text { Total sewage generated= total number of workers } 1.65 \mathrm{~kg} / \text { day } / \text { person } \\
\text { (Solid and liquid excreta production) } \text { (Munoz et. al., 2007) }\end{array}$ \\
\hline & Total liquid waste & Total liquid waste = Sullage + Sewage \\
\hline
\end{tabular}

\section{- Solid Waste}

The solid waste was categorized as poultry manure/litter, office waste, dust produced, cracked eggs and dead birds. Solid waste was assessed by estimating the total manure production, rate of dead birds, total damaged eggs, amount of dust and office waste generation. The data was analyzed, manipulated from the Nepal Commercial Poultry Survey 2015. The average mortality rate of a flock is from 20 to 25 percent per year, so average of 22.5 percent was estimated for calculation of mortality of poultry. In general, optimum body weight during the laying period should be around 1.7 to $1.8 \mathrm{~kg}$, although this varies according to breed (Poultry Hub, 2019), so $1.75 \mathrm{~kg}$ weight was estimated for determining mortality of poultry. The hatchable eggs of Cobb 500 were classified according to three different egg weight groups as small: (<49 g) medium: (50-59 g) and large: (60-69 g) (Ramaphala, 2013). The average weight of $59 \mathrm{~g}$ was taken for calculation of cracked eggs. According to Nepal Commercial Poultry Survey 2014-2015 (CBS 2016), the damaged egg ranged between 1- 6\% of total egg production. Average 3\% damaged egg was taken for the calculation of cracked eggs.

Table3. Solid waste

\begin{tabular}{|c|c|c|}
\hline S.N. & Categories of solid waste & Methods \\
\hline 1 & Poultry litter/manure & $\begin{array}{l}\text { Total manure production = number of birds of each poultry species X } \\
\text { manure production per birds of each poultry species (Collins et al., } \\
\text { 1999) }\end{array}$ \\
\hline 2 & Dead birds & $\begin{array}{l}\text { Mortality rate }=\text { Mortality rate }(22.5 \%) \mathrm{X} \text { total number of birds in farm } \\
\text { X Optimum body weight per bird }(1.7 \text { to } 1.8 \mathrm{Kg})(\mathrm{FAO}, 2003 \text { \& Poultry } \\
\text { Hub 2019) }\end{array}$ \\
\hline 3 & Cracked eggs & $\begin{array}{c}\text { Total egg cracks }=3 \% \text { of total eggs produced X Average weight of egg } \\
(59 \mathrm{~g})(\text { Ramaphala, 2013) }\end{array}$ \\
\hline 4 & Office waste & $\begin{array}{l}\text { The average daily waste generation waste is } 1.4 \mathrm{~kg} \text { per office (ADB, } \\
2013 \text { ) }\end{array}$ \\
\hline 5 & Dust & $\begin{array}{l}\text { Total amount of dust generated = total area of farm X Average height of } \\
\text { farm }(3 \mathrm{~m}) \times 5.075 \mathrm{mg} / \mathrm{m} 3 \text { (Alchalabi, 2014 \& Ellen et.al., 2000) }\end{array}$ \\
\hline & Total solid waste & $\begin{array}{c}\text { Total solid waste }=\text { Total manure production }+ \text { Dead Birds }+ \text { Cracked } \\
\text { eggs }+ \text { Office waste }+ \text { Dust }\end{array}$ \\
\hline
\end{tabular}

\subsubsection{Green House Gases (GHGs) Emission from Poultry}

Large amount of waste from poultry comes from poultry manure and methane is major source of GHG from the poultry manure. So, this study only considered methane emission from manure management of poultry farm. Emission of methane from manure management was calculated using GHG calculation tools and emission factors from IPCC 2006. The IPCC 2006 default $\mathrm{CH}_{4}$ emission factors for poultry manure management, combined with the annual average temperature of Nepal, were used to estimate $\mathrm{CH}_{4}$ emission from manure management. Equation 10.22 of IPCC 2006, was used to determine the $\mathrm{CH}_{4}$ emission from manure management. Emission factor $0.02 \mathrm{~kg} \mathrm{CH}_{4} / \mathrm{head} / \mathrm{yr}$ 
was used for estimating $\mathrm{CH}_{4}$ emission. $\mathrm{CH}_{4}$ emission was estimated based on data from Nepal commercial poultry survey 2015.

$\mathrm{CH}_{4 \text { Manure }}=\sum_{(T)} \frac{E F(T) x N(T)}{10^{\wedge} 6}$

Where,

$\mathrm{CH}_{4}$ Manure $=\mathrm{CH}_{4}$ emissions from manure management, for a defined population, $\mathrm{Gg} \mathrm{CH}_{4} \mathrm{yr}^{-1}$

$\mathrm{EF}_{(\mathrm{T})}=$ emission factor for the defined population, $\mathrm{Kg} \mathrm{CH}_{4}$ head $^{-1} \mathrm{yr}^{-1}$

$\mathrm{N}(\mathrm{T})=$ the number of head of poultry species/categories $\mathrm{T}$ in the country

$\mathrm{T}=$ Species/categories of poultry

\section{ReSUlts}

\subsection{Environmental Impacts of Poultry Farms}

The construction and operation of poultry farms have both positive and negative impacts in environment. The impacts of poultry farm in environment were categorized into physical, biological, social-economic impacts. From the case study of four poultry farm the following significant impacts were identified based on National EIA Guideline 1993. Adverse impacts from the poultry farm were primarily focused in this paper.

\subsubsection{Beneficial Impacts}

Poultry farm produce poultry manure rich in nitrogen and organic matter and are considered as valuable fertilizer for the farmers to increase their agricultural productivity. Major significant impacts were found in socio-economic environment from the operation of poultry farm that include easy availability of organic fertilizer to farmers, reduce dependency on inorganic fertilizer, employment generation, improve economic status of local people, easy access of food i.e. egg and meat.

\subsubsection{Adverse Impacts}

\subsubsection{Physical Impacts}

From the four poultry farm, impacts i.e. change in land use pattern, waste generation, odor generation, air pollution, noise pollution, water pollution, soil pollution and decrease in aesthetic beauty were identified that has adverse impacts in physical environment.

\section{* Change in Land use Pattern}

Construction activities like site clearing, excavation, cutting, filling, leveling and other activities changes the land use pattern. Change in land use pattern affected the social life of local people as agricultural land was turned into poultry farm leading to decrease the agricultural production.

\section{* Waste Generation}

One of the biggest concern of poultry farm is waste generation. The poultry farm produces large amount of waste which include both solid and liquid waste. The solid waste was generated from bedding materials, manure, feed, feathers, broken eggs and dead birds. Large quantity of solid wastes generated cause pollution of the surrounding environment and affect the health of local people and their livestock. The solid waste composition of study area is presented below;

Table4. Waste Composition of Study Sites

\begin{tabular}{|c|c|c|c|c|c|c|c|}
\hline S.N. & Site & $\begin{array}{c}\text { Poultry } \\
\text { manure } \\
\text { (tons/yr) }\end{array}$ & $\begin{array}{c}\text { Dead } \\
\text { birds } \\
\text { (tons/yr) }\end{array}$ & $\begin{array}{c}\text { Office } \\
\text { waste } \\
\text { (tons/yr) }\end{array}$ & $\begin{array}{c}\text { Dust } \\
\text { generated in } \\
\text { shed (tons/yr) }\end{array}$ & $\begin{array}{c}\text { Cracked } \\
\text { eggs } \\
\text { (tons/yr) }\end{array}$ & $\begin{array}{c}\text { Total solid } \\
\text { waste } \\
\text { (tons/yr) }\end{array}$ \\
\hline 1 & Site I & 4073.4 & 36.61875 & 0.511 & 0.05746 & 39.5064 & 4150.09361 \\
\hline 2 & Site II & 3066 & 27.5625 & 0.511 & 0.04325 & 23.01 & 3117.12675 \\
\hline 3 & Site III & 2190 & 19.6875 & 0.511 & 0.03089 & 21.24 & 2231.46939 \\
\hline 4 & Site IV & 3504 & 31.5 & 0.511 & 0.04943 & 33.984 & 3570.04443 \\
\hline & Average & 3208.35 & 28.84219 & 0.511 & 0.045256 & 29.4351 & 3267.183545 \\
\hline
\end{tabular}

This study estimated $98 \%$ of solid waste generated from poultry manure and $2 \%$ from other sectors which include dead birds, cracked eggs, office waste and dust from poultry shed. 


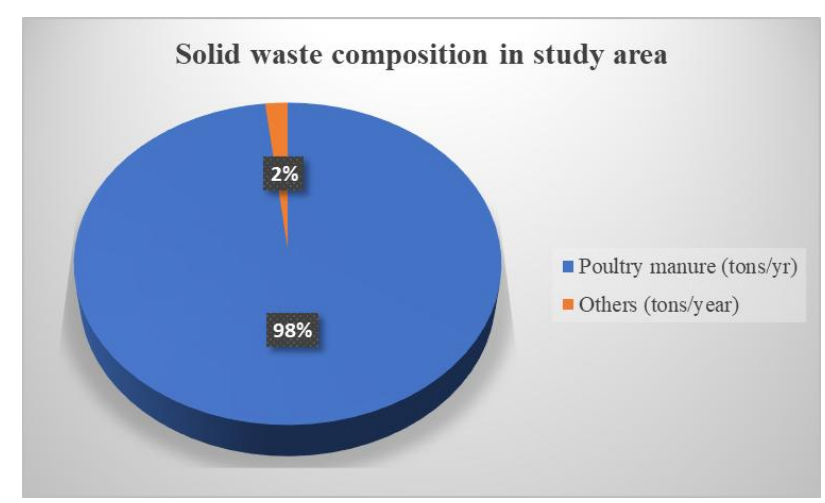

Effluents from poultry operation contaminate surface water and groundwater providing ideal habitat for insects (flies). Effluents from poultry operations typically have a high content of organic material and consequently a high Biochemical Oxygen Demand (BOD) and Chemical Oxygen Demand (COD), as well as nutrients and Total Suspended Solids (TSS). Among the four-study area, site IV produced large amount of liquid waste i.e. $1527.48 \mathrm{~m}^{3} / \mathrm{yr}$, while site II generated $663 \mathrm{~m}^{3}$ liquid water annually. Annually site I and site III generated 935.76 and $1521.14 \mathrm{~m}^{3}$ liquid water respectively.

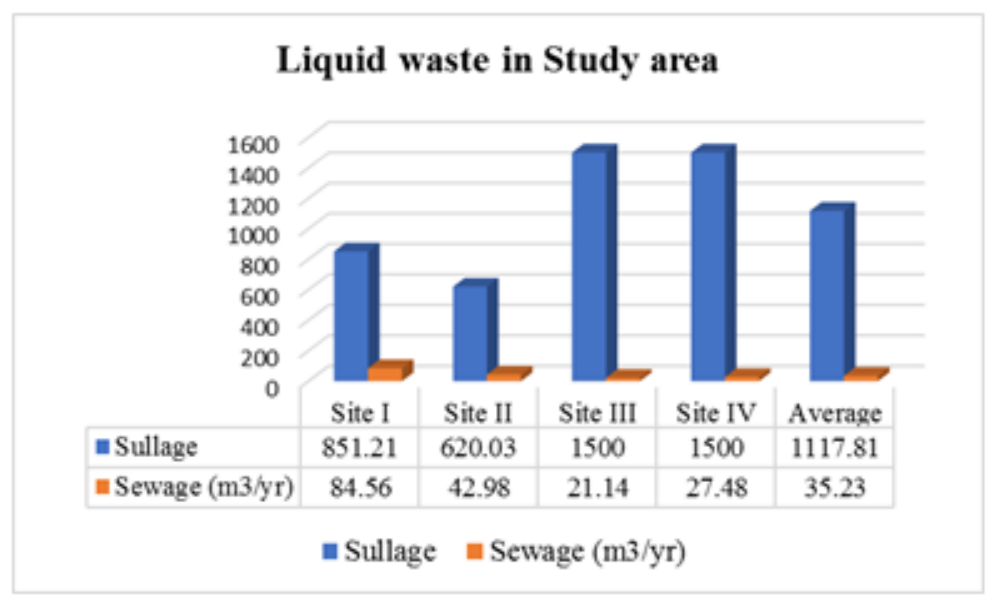

\section{* Odor Generation}

Odor associated with poultry operations comes from fresh and decomposing waste products such as manure, dead birds, feathers and bedding material that degrades the quality of air and adversely affect life of people living in the vicinity.

\section{* Water Pollution}

Wastewater production from runoff, leakages and leaching of nutrient and pathogen from manure storage cause surface and groundwater pollution. Nutrient rich wastewater when end up in water resources contribute to water quality problems and eutrophication.

\section{* Emission of GHGs like Methane, Ammonia, Nitrous oxide, etc.}

Burning of fossil fuels for heating the poultry farm and manure management activities contribute to emission of GHGs. These gases contribute to global warming to some extent.

\subsubsection{Biological Impacts}

\section{* Transmission of Zoonotic Disease}

There is a risk of transmission of zoonotic diseases from poultry farm to human. Both poultry manure and carcasses contain pathogenic organisms which can infect human leading to zoonotic diseases caused by Campylobacter and Salmonella species which are found in poultry manure. Viruses such as the H5N1 strain of avian influenza "bird flu" can also transfer from poultry to humans.

\section{* Increase in Number of Flies/ Insects}

Poultry facilities are a source of odor and attract flies, rodents and other pests that create local nuisances and carry disease. Flies can transmit diseases, such as cholera, dysentery, and other diseases. 


\subsubsection{Socio-Economic Impacts}

\section{* Occupational Health and Safety}

Workers are exposed to different health and safety hazards in poultry farm. Workers may be exposed to odor, dust and a range of pathogens such as bacteria, fungi, mites and viruses (including "bird flu") transmitted from live birds, excreta, carcasses and parasites and ticks.

\section{* Change in Occupation}

Operation of poultry farm generate employment opportunity among local people resulting in high chance of changing occupation of people. It affects lifestyle and culture of people.

\subsection{Waste Generation from Poultry in Nepal}

\subsubsection{Province Level Poultry Liquid Waste Generation in Nepal}

In Nepal, largest number of poultry farm are in province 3 i.e. 7638, so largest amount of liquid waste is generated from province 3 i.e. 288.12 million liters/year. Annual production of liquid waste is 9.97 million liters in Karnali province contributing least in liquid waste generation in Nepal. Similarly, 72.94, 68.79, 76.59, 75.31 and 27.13 million 1/yr liquid waste is generated from 1, 2, Gandaki, 5 and Sudurpaschim province respectively. Of the total liquid waste generation from poultry farm, $47 \%$ liquid waste is contributed by province 3 while least contribution i.e. $2 \%$ by Karnali province.

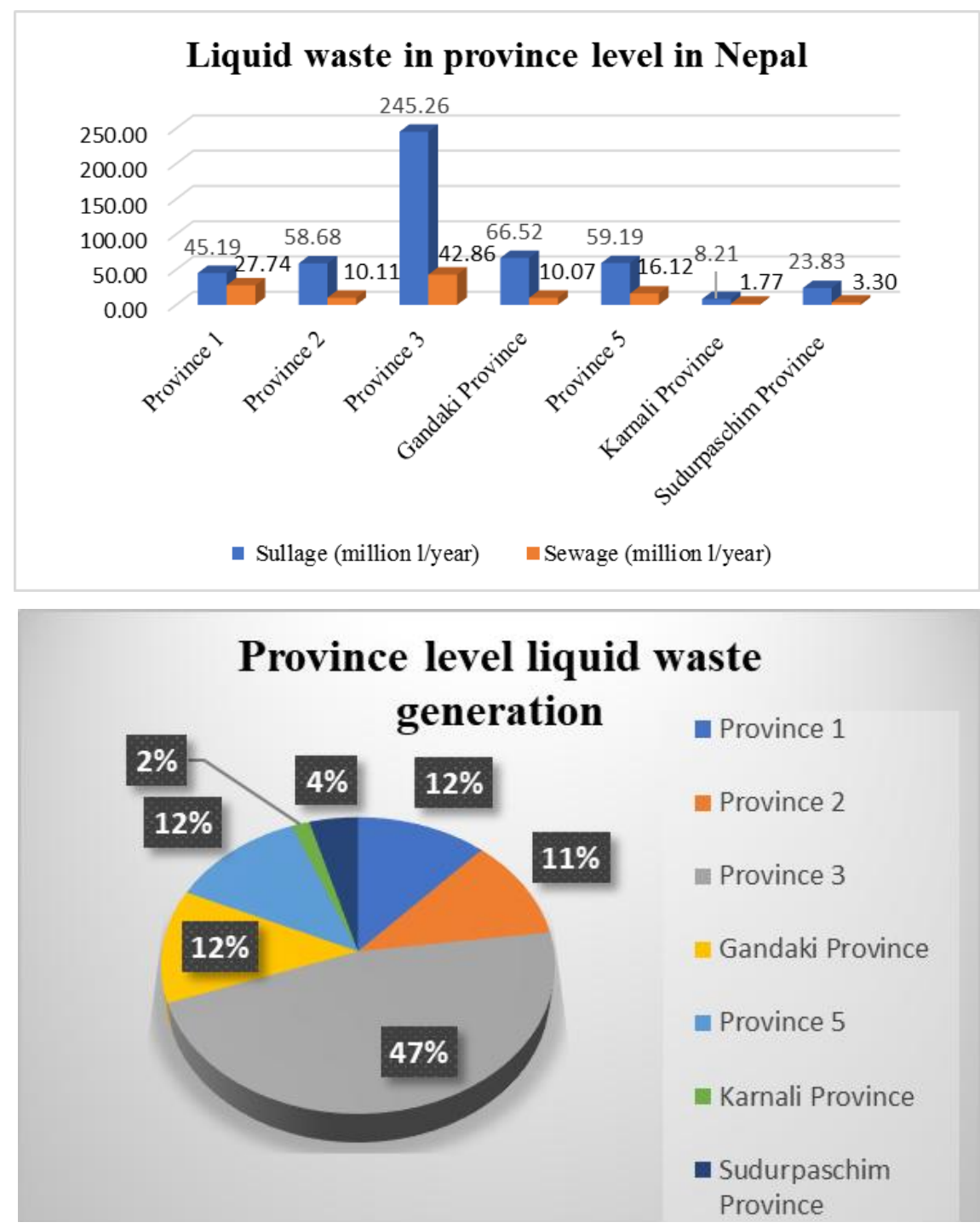

\subsubsection{Poultry Liquid Waste Generation in Nepal}

The annual liquid waste generation in Nepal is 618.86 million liters. $81.91 \%$ of liquid waste generated from effluents from various sources including runoff from poultry housing, cleaning of poultry farm. $18.09 \%$ of liquid waste is generated from the latrine during the operation of poultry farm. 


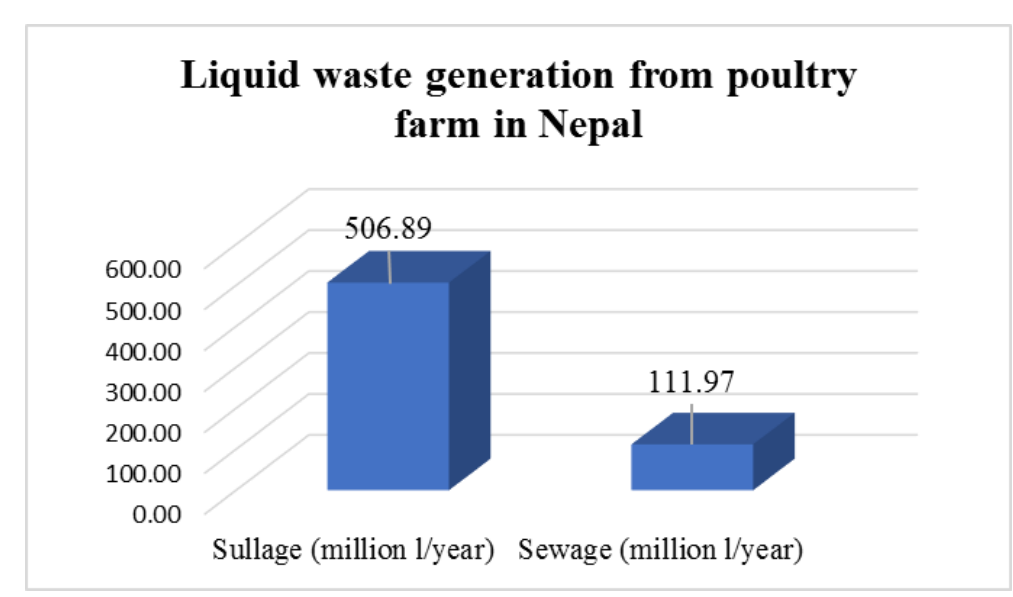

\subsubsection{Province Level Poultry Solid Waste Generation in Nepal}

\section{* Poultry Manure and Dead Birds}

Annual production of poultry manure is $0.24,0.31,1.29,0.35,0.31,0.04$ and 0.13 million tons in 7 provinces of Nepal respectively. Similarly, province 1, 2, 3, Gandaki, 5, Karnali and Sudurpaschim generate 2135.44, 2772.72, 11588.55, 3143.14, 2796.79, 387.77 and 1126.16 tons of dead birds annually. Province 3 has highest contribution for manure and dead bird production. Largest amount of solid waste is generated from poultry manure in poultry farm.

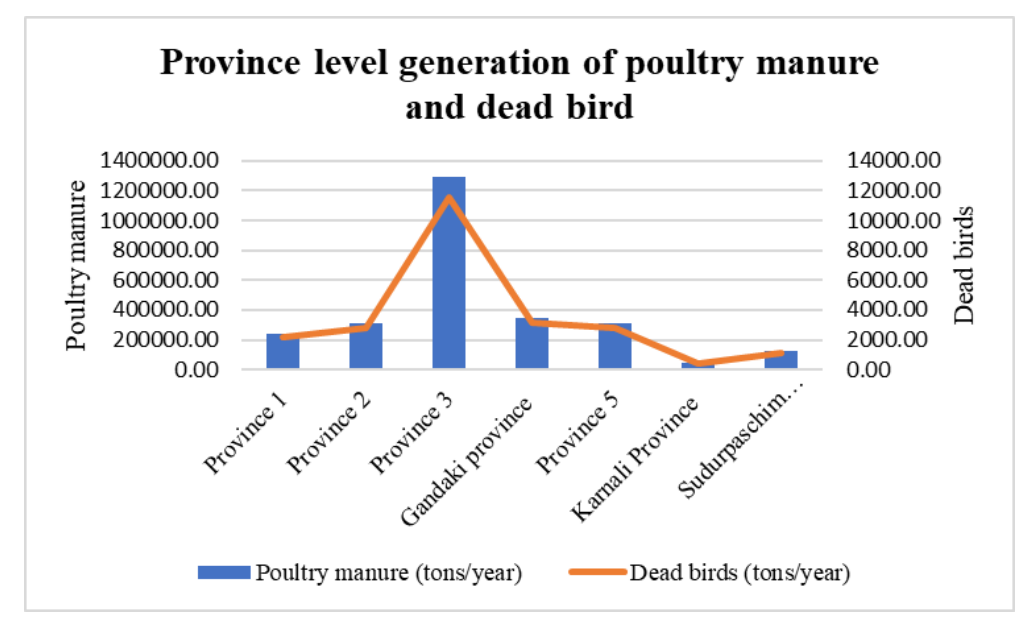

\section{* Office Waste and Dust Generation}

Largest amount of office waste and dust are generated from province 3 i.e. 3903.02 tons/year and 0.15 tons/year respectively. While negligible amount of dust and least amount of office waste i.e. 441.50 tons/year is generated from province 6 .

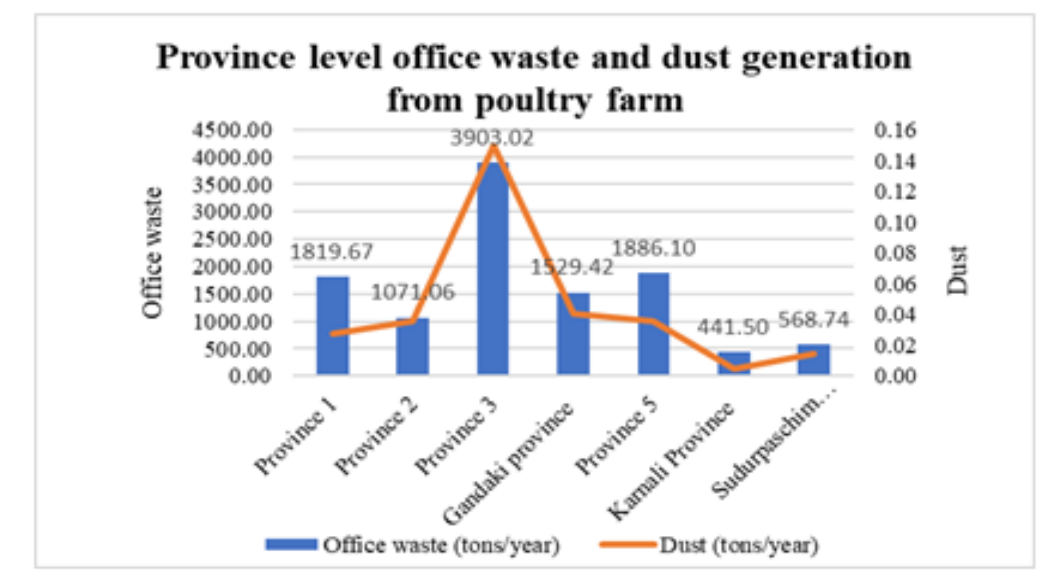

\section{* Cracked Eggs}

Annually largest amount i.e. 1736.63 tons of cracked eggs are generated from province 3 . 


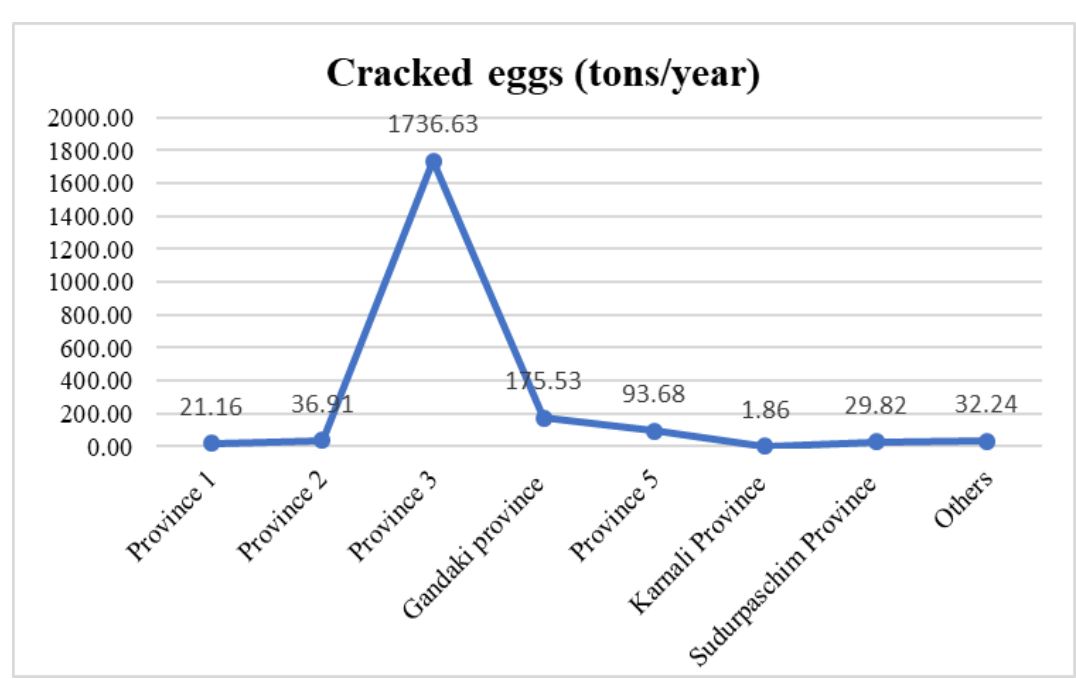

Others include Dhankuta, Khotang, Dhanusa, Rasuwa, Gulmi, Rupandehi, Arghakanchi, Salyan and Banke district

\section{Total Solid waste Generation in Province Level}

Largest volume of solid waste is generated in province 3 i.e. 1.31 million tons/ yr, while least in Karnali province i.e. 0.04 million tons/ yr. similarly $0.24,0.31,0.35,0.32$ and 0.13 million tons/ yr generated from 1, 2, 4, 5 and Sudurpaschim province respectively. Of the total solid waste generation from poultry farm, $48 \%$ solid waste is contributed by province 3 while least i.e. $2 \%$ is contributed by Karnali province.

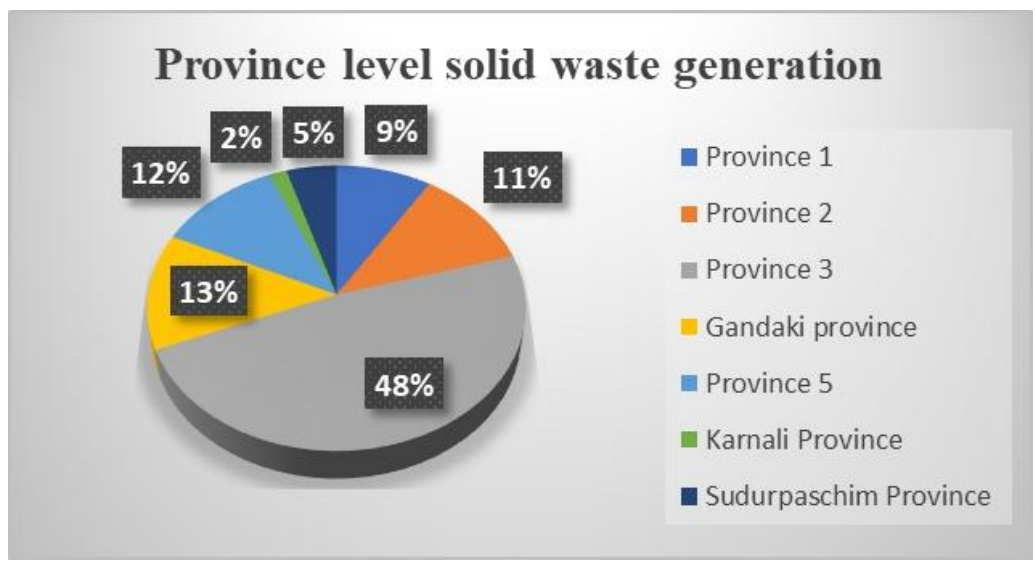

\subsubsection{Poultry Solid Waste Generation in Nepal}

Annually 2.7 million tons solid waste is generated from poultry farm in Nepal. $99 \%$ of poultry solid waste is generated from poultry manure i.e. 2.66 million tons/year. $1 \%$ of waste are generated from dead birds, office waste, dust and cracked eggs.

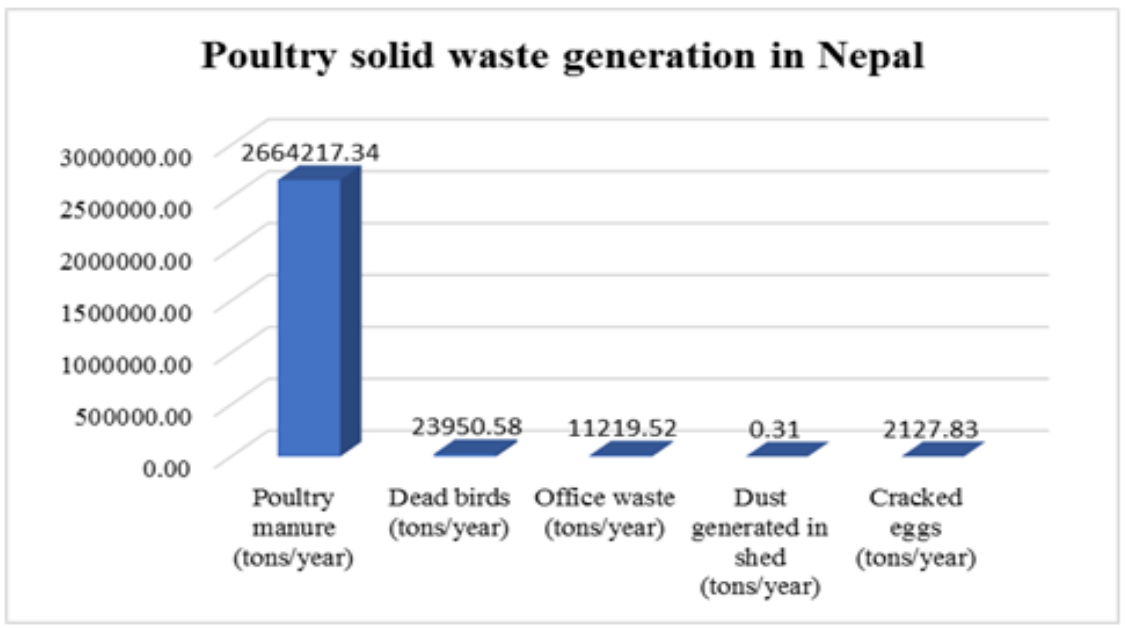




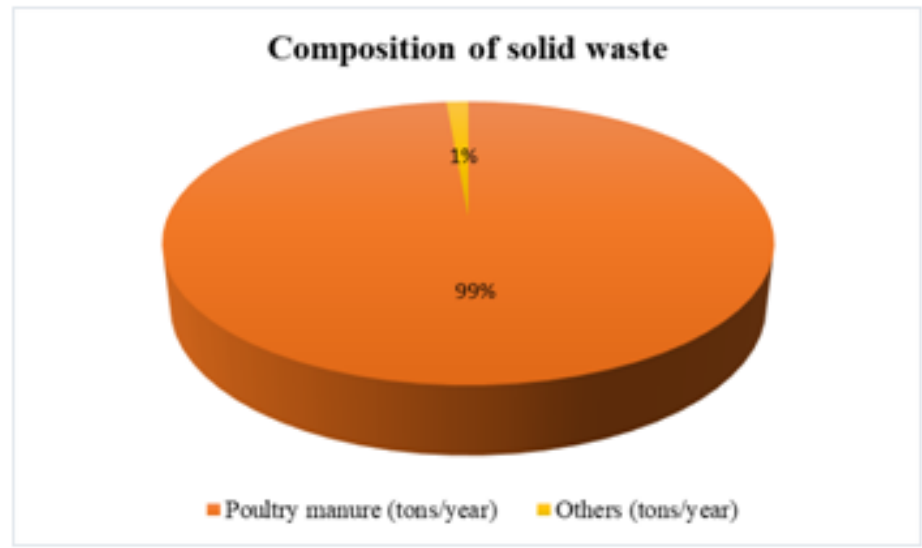

\subsection{Emission of Methane from Poultry Farm in Nepal}

Annually $30.41 \mathrm{Gg} \mathrm{CO}_{2}$ equivalent of $\mathrm{CH}_{4}$ is emitted from manure management from poultry farm in Nepal. From broilers chickens, largest amount of $\mathrm{CH}_{4}$ gas is released followed by layers and others (Giriraj, Koilers).

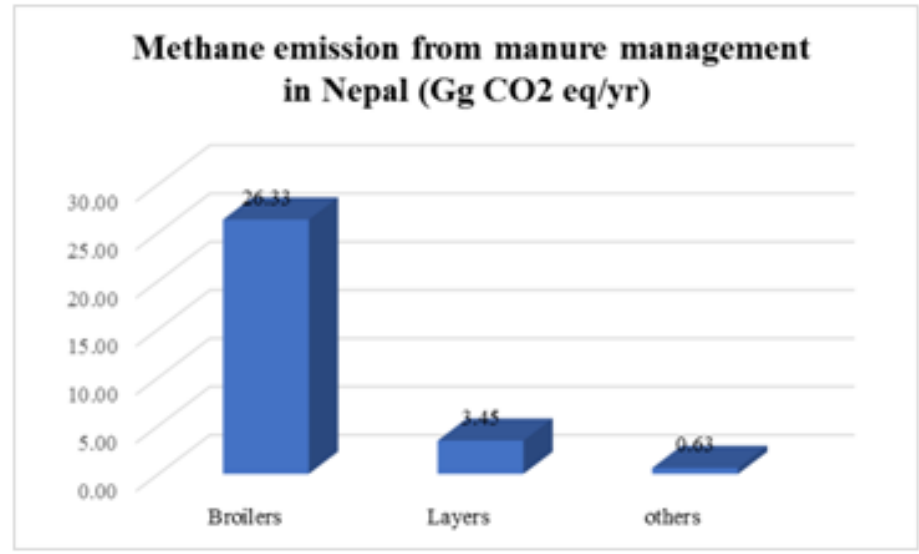

\section{DISCUSSION}

Increasing demand for meat and egg supply has resulted in growth and intensification of poultry sector which has raised number of environmental concerns (Gerber, Opio, \& Steinfeld, 2007). The poultry industry produces large amounts of waste that include solid waste and wastewater. These waste if not properly disposed can be risky to the environment and humans through the spread of diseases and pollution of soil and groundwater. Pollution of soil and water with nutrients, pathogens and heavy metals is generally caused by poor manure-management. Poultry facilities are a source of odor that comes from fresh and decomposing waste products such as manure, carcasses, feathers and bedding/ litter (Kolominskas, Bawden, \& Ormerod, 2002) and attract flies, rodents and other pests that adversely affect the life of people living in the vicinity (Gerber, Opio, \& Steinfeld, 2007). According to Edward and Daniel (1991), the primary waste of concern is the manure, which may be mixed with floor material depending on the type of poultry production (broilers, layers, etc.) followed by dead birds similar to our study.

\section{- Liquid Waste}

Liquid waste generated from poultry include various sources including runoff from poultry housing, cleaning and disinfection and sewage from workers. The volume of water used for cleaning purposes varies depending on the technique applied and the water pressure used for cleaning. According to EC 2003 , annual water consumption for cleaning the areas of poultry is $251 / \mathrm{m}^{2} /$ year $\left(0.025 \mathrm{~m}^{3} / \mathrm{m}^{2} / \mathrm{yr}\right)$. The average daily solid and liquid excreta production by an average person is 1.931 (1.65 kg i.e. 1.51 urine and $0.15 \mathrm{~kg}$ faeces) (Munoz et. al., 2007).

\section{- Solid Waste}

Poultry meat and eggs provide affordable, quality food products worldwide. The production of poultry results in manure (bird excrement), litter (bedding materials such as sawdust, wood shavings, straw 
and peanut or rice hulls), and on-farm mortalities (Williams, 2013). The composition and quality of a poultry manure varies with the types of poultry, types of litter produced, diet and dietary supplements, and collection and storage of the litter (Reza, 2016). Poultry manure contains considerable amounts of nutrients such as nitrogen, phosphorus, and other excreted substances such as hormones, antibiotics, pathogens and heavy metals which are introduced through feed (Steinfeld, et al., 2006). Leaching and runoff of these substances has the potential to result in contamination of surface water and groundwater resources. Miner and Smith (1975) estimated that $13.4 \mathrm{~kg}$ (dry basis) per day of manure are produced for each $1000 \mathrm{~kg}$ layers birds. Similarly, $17.1 \mathrm{~kg}$ (dry basis) of manure are produced daily per $1000 \mathrm{~kg}$ broiler live weight which is in close agreement with value of $17.37 \mathrm{~kg}$ of manure in Nepal reported from our study.

Mortality rate in poultry farm may rise due to disease, predation or high temperature. The mortality rate of small chicks (up to eight weeks of age) is about 4 percent; that of growers (between eight and 20 weeks of age) is about 15 percent; and that of layers (between 20 and 72 weeks of age) is about 12 percent. The average mortality rate of a flock is from 20 to 25 percent per year (FAO, 2003).

Poultry farms generate dust, which originates from bedding materials, fiberglass insulations, feed, dried fecal materials, and feather particles. Dust concentrations in poultry houses vary from 0.02 to $81.33 \mathrm{mg} / \mathrm{m}^{3}$ for inhalable dust and from 0.01 to $6.5 \mathrm{mg} / \mathrm{m}^{3}$ for respirable dust. Houses with caged laying hens showed the lowest dust concentrations, i.e., less than $2 \mathrm{mg} / \mathrm{m}^{3}$ (Ellen et.al. 2000). According to ADB 2013, an average of $1.4 \mathrm{~kg}$ waste is produced daily by an office. Study done by Roland 1988, estimated 6-10\% of all eggs produced are damaged leading to great economic losses. Our study estimated 1-6\% of total egg produced are damaged, caused either by the birds themselves or as a result of poor management practices, such as infrequent collection of eggs, rough handling and poor design and/or maintenance of the cage floor. Egg shell strength ultimately affects the soundness of the shell, with weaker shelled eggs more prone to cracks and breakages and subsequently microbial contamination (Yoruk, Gul, Hayirli, \& Karaoglu, 2004). The occurrence of broken eggs directly depends on the quality of the shell. Shell strength can be affected by a wide range of factors including egg size, age of bird, stress to a flock of laying hens, elevated environmental temperature, nutrition and water quality, etc. (Chukwuka, et al., 2011). The harsh tropical climate and severe disease outbreaks, poor biosecurity, sub-minimal vaccination and treatment protocols, poor management practices, poor chick quality, feed-associated causes, and unintended accidents often aggravate mortality and negatively affect egg production (Shittu, 2014).

Poultry farm in Nepal emit $30.41 \mathrm{Gg} \mathrm{CO} 2$-eq of $\mathrm{CH}_{4}$ annually from manure management from poultry farm in Nepal. Largest amount of $\mathrm{CH}_{4}$ is released from broilers chicken followed by layers and others (Giriraj, Koilers) in Nepal. The total GHG emissions from layer chickens were higher than from broiler chickens (Boontiam, Shin, Choi, \& Kumari, 2016). But in our study emission was higher from broilers, it may be due to larger number of broilers than layers and koilers.

\section{CONCLUSION}

This study objectively focused on the impacts, composition of waste generation and Green House Gases emission limited to methane gas generated from poultry farm. Study identified the significant environmental impacts associated with poultry farm. Poor management of manure, bird carcasses, dust, insects, odor, etc. generated from the poultry operation adversely affects the environment. Furthermore, intensive poultry production is held responsible for the emission of greenhouse gasses, water pollution. The environmental impact of poultry production depends on numerous factors, such as farm size, production system, diet composition, type of bedding used, etc.

Change in land use pattern, waste generation, odor generation, air pollution, noise pollution, water pollution, soil pollution and decrease in aesthetic beauty are the few adverse physical impacts from poultry farm. Transmission of zoonotic disease, increase in number of flies are the adverse impacts in biological environment associated with poultry operation. Operation of poultry adversely affect the occupational health and safety of workers through exposure to different safety hazards and odor, dust and pathogens transmitted from live birds, excreta, carcasses and parasites and ticks.

One of the biggest concern of poultry farm is waste generation. From the case study of four poultry farm, average of 3267.18 tons solid waste and $1153.04 \mathrm{~m}^{3}$ liquid waste were generated annually. $98 \%$ of solid waste was generated from poultry manure.

Of the total liquid waste generation from poultry farm in Nepal, largest amount i.e. $47 \%$ (288.12 million liters/year) liquid waste is contributed by province 3 while least i.e. 2\% (9.97 million 
liters/year) contributed by province 6 . The annual liquid waste production in Nepal is 618.86 million liters. $81.91 \%$ of liquid waste generated from effluents from various sources including runoff from poultry housing, feeding, and watering; from waste storage and management facilities. $18.09 \%$ of liquid waste is generated from the latrine during the operation of poultry farm.

Of the total solid waste generation from poultry farm in Nepal, $48 \%$ (1.31 million tons/year) solid waste is contributed by province 3 while least contribution i.e. $2 \%$ (0.04 million tons/year) by province 6. Annually 2.7 million tons solid waste is generated from poultry farm in Nepal. $99 \%$ of poultry solid waste is generated from poultry manure i.e. 2.66 million tons/year.

Annually $30.41 \mathrm{Gg} \mathrm{CO} 2$-eq of $\mathrm{CH}_{4}$ is emitted from manure management from poultry farm in Nepal. Largest amount of $\mathrm{CH}_{4}$ is emitted by broilers chicken. The major factors affecting $\mathrm{CH}_{4}$ emission are the amount of manure produced and the portion of the manure that decomposes anaerobically.

\section{REFERENCES}

[1] ABD. (2013). Solid waste management in Nepal: Current status and policy recommendations. Mandaluyong City, Philippines: Asian Development Bank.

[2] Acharya, K. P., \& Kaphle, K. (2015). Major Issues for Sustainable Poultry Sector in Nepal . Global Journal of Animal Scientific Research, 227-239.

[3] Alchalabi, D. (2014). Poultry Housing Design.

[4] Boontiam, W., Shin, Y., Choi, H. L., \& Kumari, P. (2016). Assessment of the contribution of poultry and pig production to Greenhouse Gas emissions in South Korea over the last 10 yeras (2005 through 2014). Asian Australas Journal Animal Science, 1805-1811.

[5] CBS. (2012). Statistical Year Book of Nepal. National Planning Commission, Nepal. Kathmandu: Central Bureau of Statistics.

[6] CBS. (2016). Nepal Commercial Poultry Survey 2015. Thapathali, Kathmandu: Central Bureau of Statistics.

[7] Chukwuka, O. K., Okoli, I. C., Okeudo, N. J., Udedible, A. B., Ogbuewu, I. P., Aladi, N. O., . . Omede, A. A. (2011). Egg Quality Defects in Poultry Management and Food Safety. Asian Journal of Agricultural.

[8] Collins, E., Barker, J., Carr, L., Brodie, H., \& Martin, J. (1999). Poultry waste management handbook. Ithaca, New York, USA: Natural Resource, Agriculture, and Engineering Service (NRAES).

[9] EC. (2003). Integrated Pollution Prevention and Control (IPPC). Reference Document on Best Available Techniques for Intensive Rearing of Poultry and Pigs.

[10] Edwards, D. R., \& Daniel, T. C. (1991). Environmental Impacts of On-Farm Poultry WasteDisposal. Bioresource Technology, 9-33.

[11] Ellen, H. H.; Bottcher, R. W.; Wachenfelt, E. von; Takai., H. (2000). Dust Levels and Control Methods in Poultry Houses. Journal of Agricultural Safety and Health, 6(4), 275-282. doi:10.13031/2013.1910

[12] FAO. (2003). Egg marketing: A Guide for production and sale of eggs.

[13] FAO. (2014). Poultry Sector Nepal. FAO Animal Production and Health Livestock Country. Rome : Food and Agriculture Organization .

[14] FAO. (2019). Gateway to poultry production and products. Retrieved from http://www.fao.org/poultryproduction-products/production/poultry-species/en/

[15] Ferket, P. R., Van Heugten, E., Van Kempen, T. G., \& Angel, R. (2002). Nutritional strategies to reduce environmental emissions from non-ruminants. Journal of Animal Science, 168-182.

[16] Gerber, P., Opio, C., \& Steinfeld, H. (2007). Poultry production and the environment-a review. Animal production and health division, Food and Agriculture Organization of the United Nations, Viale delle Terme di Caracalla,.

[17] Intergovernmental Panel on Climate Change (IPCC). (2006). IPCC Guideliness for National Greenhouse Gas Inventories . IPCC.

[18] International Finance Corporation, World Bank Group. (2007). Environmental, Health, and Safety Guidelines for Poultry Production. International Finance Corporation. Retrieved 8 23, 2019, from https://www.ifc.org/wps/wcm/connect/26828301-873b-4497-99f0-5b7e9123dcfe/Final\%2B$\% 2$ BPoultry\%2BProduction.pdf?MOD=AJPERES \&CVID=jkD2FoC

[19] Kolominskas, C., Bawden, K., \& Ormerod, R. (2002). Strategies to reduce odour emissions from meat chicken farms. 27-39.

[20] Miner, J. R., \& Smith, R. S. (1975). Livestock waste management with pollution control. North Central Regional Research Publication . 
[21] Mishra, B. (2013). Poultry in Nepal: Present scenario, Indigenous breeds and Economic traits.

[22] MoF. (2018). Economic Survey 2017/2018. Singh Durbar, Kathmandu: Ministry of Finance, Government of Nepal.

[23] Muduli, S., Champati, A., Popalghat, H., Patel, P., \& R Sneha, K. (2018). Poultry waste management: An approach for sustainable development.

[24] Muñoz, I., Canals, L. M., Clift, R., \& Doka, G. (2007). A simple model inclde Human Excretion and Wastewater treatment in Life Cycle Assessment of Food products. Guildford (Surrey) GU2 7XH, United Kingdom: Centre for Environmental Strategy, University of Surrey,.

[25] NRAES. (1999). Poultry Waste Management Handbook (NRAES-132). 152 Riley-Robb Hall, Ithaca, NY: Natural Resource, Agriculture, and Engineering Service, Cooperative Extension.

[26] Osti, R., Bhattarai, D., Chaudhary, H., \& Singh, V. (2016). An Economic Analysis of Poultry Egg Production in Nepal. Pakistan Journal of Nutrition, 15(8), 715-724. doi:10.3923/pjn.2016.715.724

[27] Pelletier, N. (2008). Environmental performance in the US broiler poultry sector: Life cycle energy use and greenhouse gas, ozone depleting, acidifying and eutrophying emissions. Agricultural system, Elsevier, 67-73.

[28] Poultry Hub. (2019). Nutrients requirements of egg laying chickens. Retrieved from http://www.poultryhub.org/nutrition/nutrient-requirements/nutrient-requirements-of-egglaying-chickens/

[29] Pradhanang, U., Pradhanang, S., A., S., \& T, K. N. (2015). National Livestock Policy of Nepal: Needs and Opportunities (Vol. 5).

[30] Ramaphala, N., \& C.A. Mbajiorgu. (2013). Effect of Egg Weight on Hatchability and Chick Hatch-weight of COBB 500 Broiler Chickens. Asian Journal of Animal and Veterinary Advances, 8, 885-892.

[31] Reza, S. (2016). Poultry Litter - A Great Resource to Utilize. Retrieved 9 13, 2019, from Permaculturenews: https://permaculturenews.org/2016/03/11/poultry-litter-a-great-resource-to-utilize/

[32] Robert, T. B. (2012). Poultry production and climate change.

[33] Rodic, V., Peric, L., Stojcic, M. D., \& Vukelic, N. (2011). The environmental impact of poultry production. Biotechnology in Animal Husbandry, 1673-1679.

[34] Roland, S. D. (1988). Research note: egg shell problems: estimates of incidence and economic impact. Poultry Science, 67, 1801-1803.

[35] Sharma, B. (2010). POULTRY PRODUCTION, MANAGEMENT AND BIO-SECURITY MEASURES. The Journal of Agriculture and Environment.

[36] Shittu, A., Raji, A. A., Madugu, S. A., Hassan, A. W., \& Oludayo, F. F. (2014). Predictors of death and production performance of layer chickens in opened and sealed pens in a tropical savannah environment. BMC Veterinary Research, 10(1). doi:10.1186/s12917-014-0214-7

[37] Sonaiya, E., \& Swan, S. (2004). Small-scale poultry prodcution. Retrieved from Food and Agricultural Organization of the United State: http://www.fao.org/3/y5169e/y5169e05.htm

[38] Steinfeld, H., Gerber, P., Wassenaar, T., Castel, V., Rosales, M., \& Haan, C. d. (2006). Livestock's long shadow: environmental issues and options. Rome: Food and Agricultural Organization (FAO).

[39] United Nations Economic and Social Commission for Asia and the Pacific (ESCAP), United Nations Human Settlements Programme (UN-Habitat), Asian Institute. (2015). Policy Guidance Manual on Wastewater Management.

[40] USAID. (2019). AGRICULTURE AND FOOD SECURITY. Retrieved 8 23, 2019, from USAID Nepal: https://www.usaid.gov/nepal/agriculture-and-food-security

[41] Verge, X. C., Dyer, J. A., Desjardins, R. L., \& Worth, D. (2009). Long-term trends in greenhouse gas emissions from the Canadian poultry industry . The Journal of Applied Poultry Research, 210-22.

[42] Williams, C. M. (2013). Poultry waste management in developing. In the role of poultry in human nutrition. Retrieved from Food and Agriculture Organization of the United Nations, Poultry Development REview.

[43] Yoruk, M. A., Gul, M., Hayirli, A., \& Karaoglu, M. (2004). Laying Performance and Egg Quality of Hens Supplemented with Sodium Bicarbonate During the Late Laying Period. International Journal of Poultry Science, 272-278.

Citation: Tej Kumar Shrestha, et.al, "Impacts, Waste Generation and Green House Gas Emission by Nepalese Poultry Industry” International Journal of Research Studies in Agricultural Sciences (IJRSAS), 2019; 5(10), pp. 9-21, http://dx.doi.org/10.20431/2454-6224.0510002

Copyright: (C) 2019 Authors. This is an open-access article distributed under the terms of the Creative Commons Attribution License, which permits unrestricted use, distribution, and reproduction in any medium, provided the original author and source are credited. 